\title{
Anemia dan Kekurangan Energi Kronis Selama Kehamilan Meningkatkan Kejadian Berat Badan Lahir Rendah (Studi Kasus Kontrol)
}

\author{
Anemia and Chronic Energy Deficiency During Pregnancy Increase Prevalence \\ of Low Birth Weight (Case Control Study)
}

\author{
Yoga Tri Wijayanti ${ }^{1, \bigotimes}$ \\ ${ }^{1}$ Jurusan Kebidann, Politeknik Kesehatan Tanjung Karang, Indonesia \\ ${ }^{\circledR}$ Corresponding author: yogatriwijayanti@gmail.com
}

\begin{abstract}
Kata kunci:
Kekurangan energi protein dan BBLR, Paritas berisiko dengan BBLR.
\end{abstract}

\begin{abstract}
Abstrak
Latar Belakang: Bayi berat lahir rendah dapat mempunyai dampak jangka panjang, antara lain gangguan perkembangan dan pertumbuhan, stunting sampai penyakit degeneratif, seperti diabetes. Tujuan: Penelitian ini untuk mengetahui hubungan paritas, anemia dan KEK dengan kejadian BBLR tahun 2016. Metode: Penelitian ini dengan rancangan studi case control retrospektif. Kasus adalah bayi badan lahir rendah < 2500 gr dilahirkan preterm atau aterm. Adapun jumlah sampel minimal yang diperlukan oleh peneliti 18 sampel kasus BBLR dengan sampel kontrol berjumlah 18 kasus yang tidak mengalami BBLR yang dipilih menggunakan teknik consecutive sampling. Analisis data menggunakan analisis univariat dan analisis bivariat menggunakan chi square. Hasil: Hasil uji statistik menunjukkan ada hubungan antara KEK dengan kejadian BBLR (nilai p 0,03 < 0,05; POR 8,0) dan ada hubungan antara paritas berisiko dengan kejadian BBLR (nilai p 0,02 < 0,05; POR 6,75). Simpulan: Ibu hamil dengan KEK berisiko meningkatkan kejadian BBLR sebesar 8,0 kali. Sedangkan, Ibu hamil dengan paritas berisiko memiliki resiko meningkatkan peluang 6,75 kali melahirkan Bayi dengan BBLR. Hendaknya ibu hamil dengan paritas tinggi melakukan rutin kunjungan kehamilan untuk melakukan deteksi dini kemungkinan komplikasi kehamilan termasuk KEK, sehingga penanganan dini dapat dilakukan dan melahirkan bayi BBLR dapat dicegah.
\end{abstract}

\begin{abstract}
Background: Low birth weight babies can have long-term effects, including developmental and growth disorders, stunting to degenerative diseases, such as diabetes. Purpose: This study was to determine the relationship of parity, anemia and KEK with LBW events in 2016. Methods: This study used a retrospective case control study design. Cases were low birth babies $<2500$ gr born preterm or term The minimum number of samples needed by researchers 18 samples of $L B W$ cases with a control sample of 18 cases that did not experience $L B W$ were selected using consecutive sampling techniques. Data analysis using univariate analysis and bivariate analysis using chi square. Results: Statistical test results showed that there was a relationship between SEZ and LBW events ( $p$ value $0.03<0.05$; POR 8.0 ) and there was a relationship between risk parity and $L B W$ events ( $p$ value 0.02 <0.05; POR 6.75). Conclusion: Pregnant women with SEZ risk increase the incidence of $L B W$ by 8.0 times. Meanwhile, pregnant women with risk parity have the risk of increasing the chance of 6.75 times giving birth to a baby with LBW. Pregnant women with high parity should carry out routine pregnancy visits to make early detection of possible pregnancy complications including $K E K$, so that early treatment can be carried out and LBW infants can be prevented.
\end{abstract}




\section{Pendahuluan}

Derajat kesehatan masyarakat dinilai dengan menggunakan beberapa indikator yang mencerminkan kondisi mortalitas (kematian), status gizi dan morbiditas (kesakitan). Target MDGs 2015 adalah menurunkan AKB menjadi 20 /1000 kelahiran hidup. Sedangkan, hasil Survei Demografi dan Kesehatan Indonesia (SDKI) tahun 2012, AKB Indonesia masih 32/1.000 kelahiran hidup dan AKB di Provinsi Lampung adalah 5/1000 kelahiran hidup (Dinas Kesehatan Provinsi Lampung, 2016). Adapun jumlah kasus kematian bayi di Kota Metro Tahun 2015 sebesar 758 kasus atau 7 per 1000 kelahiran hidup lebih besar dibandingkan angka kematian bayi pada kabupaten Lampung Tengah dan Lampung Timur (Dinas Kesehatan Provinsi Lampung, 2016). Walaupun angka kematian bayi di kota Metro masih di bawah angka MDGs, namun berdasarkan data 3 tahun berturut-turut terjadi peningkatan angka kematian bayi (AKB). Tahun 2013 angka kematian neonatal di Kota Metro adalah 3,6 kematian bayi per 1000 kelahiran hidup, sedangkan angka kematian bayi di Kota metro tahun 2014 sebanyak 5,7 per 1000 kelahiran hidup. Angka Kematian Bayi tersebut terus meningkat menjadi 7 per 1000 kelahiran hiduppada tahun 2015. Kematian Bayi di kota Metro tahun 2015 paling banyak terjadi pada masa neonatal, yaitu 17 kematian neonatal dari 22 kematian bayi yang ada di Kota Metro. Penyebab kematian bayi di Kota Metro tahun 2015 yang terbesar disumbangkan oleh BBLR dengan prevalensinya sebesar 62,5\% kemudian disusul asfiksia dan kelainan kongenital dengan prevalensi masing-masing sebesar 11,7\% (Dinas Kesehatan Kota Metro , 2016).

Berat badan lahir rendah (BBLR) merupakan bayi baru lahir yang berat badan saat lahir kurang dari 2500 gram (Saifuddin, 2009). Kejadian BBLR dapat berdampak langsung maupun jangka panjang. BBLR dapat menjadi pemicu munculnya masalah-masalah kesehatan lain pada bayi. Masalah-masalah jangka pendek seperti hipoglikemi, hipotermi gangguan elektrolit hiperbilirubinemia, sindrom gawat nafas, anemia, infeksi, perdarahan intraventrikuler, apnea of prematurity dan lain-lain (Varney, 2007). Sedangkan, dampak jangka panjang yang ditimbulkan adalah gangguan perkembangan dan pertumbuhan, kemunduran fungsi intelektual, gangguan penglihatan dan pendengaran, stunting, diabetes dan umumnya akan lebih rentan akan penyakit (Mochtar, 2005). Penelitian oleh (Mutalazimah, 2005) di RSUD Dr. Moewardi Surakarta menyatakan bahwa bayi dengan BBLR akan mengalami hambatan perkembangan dan kemunduran pada fungsi intelektualnya, dari 106 sampel ibu hamil, sebesar 13,2\% bayi yang mengalami BBLR.

Faktor penyebab terjadinya BBLR antara lain faktor ibu, janin dan plasenta. Faktor ibu yang meliputi anemia, gizi kurang (KEK), umur, paritas, jarak kehamilan, preeklamsia, hidramnion, perdarahan antepartum, hipertensi. Faktor janin meliputi cacat bawaan, hamil ganda regangan pada uterus yang berlebihan, infeksi dalam rahim, dan faktor janin meliputi abrupsio plasenta, plasenta previa, korioamnioniti (Fraser, Cooper \& Margaret, 2009).

Penyebab BBLR salah satunya adalah KEK, karena berat janin dipengaruhi pula oleh status gizi ibu pada saat konsepsi dan melahirkan (Arisman, 2010) yang dapat disebabkan oleh kekurangan gizi selama hamil, sehingga suplai zat gizi pada janin pun berkurang. Akibat KEK pertumbuhan dan perkembangan janin terhambat sampai terjadi BBLR. Hasil penelitian oleh (Mustika, 2005) di Provinsi Nusa Tenggara Barat menunjukan bahwa ada hubungan antara KEK dengan BBLR, karena pada ibu hamil yang terpapar KEK mempunyai kecendrungan 4,71 kali lebih besar mengalami BBLR dibandingkan dengan yang tidak terpapar KEK. Ibu hamil yang KEK berisiko lebih besar melahirkan BBLR dibandingkan dengan ibu hamil normal.

Pertumbuhan janin didalam rahim ibu sangat dipengaruhi oleh aliran darah dari ibu ke janin yang dihubungkan melalui plasenta, gangguan pada sirkulasi retroplasenter menimbulkan gangguan pertukaran 
nutrisi, $\mathrm{CO}_{2}$, dan $\mathrm{O}_{2}$ (Manuaba, 2012). Kadar $\mathrm{Hb}$ yang rendah dapat mempengaruhi kemampuan sistem maternal untuk memindahkan oksigen dan nutrisi yang cukup ke janin (Fraser, Cooper \& Margaret, 2009). Hasil penelitian oleh (Setiawan, Melati, \& Dirgahayu, 2009) di RSU dr. Slamet Garut memperoleh hasil anemia berisiko meningkatkan kejadian BBLR sebesar 10 kali dibanding yang tidak anemia. Penelitian ini menganalisis determinan terjadinya BBLR di kota Metro, untuk mengidentifikasi faktor penyebab atau risiko BBLR, sehingga memudahkan untuk upaya pencegahan dan bahkan menurunkan kejadian BBLR di kota Metro yang akses pelayanan dan informasi kesehatan termasuk ibu hamil sangat mudah. Akan ettapi kejadian BBLR masih tinggi. Oleh karena itu penelitian ini mengkaji beberapa determinan kejadian BBLR.

\section{Metode}

Desain penelitian ini menggunakan rancangan studi case control, yaitu suatu penelitian (survei) analitik yang menyangkut bagaimana faktor risiko dipelajari dengan menggunakan pendekatan retrospective. Efek (penyakit atau status kesehatan) diidentifikasikan pada saat ini, kemudian faktor risiko diidentifikasi ada atau terjadinya pada waktu yang lalu. Pemilihan rancangan studi case control karena jumlah kasus BBLR terbatas di lokasi penelitian wilayah Metro Barat selama tahun 2015 hanya 11,2\% dibandingkan seluruh bayi lahir hidup di tahun yang sama. Rancangan penelitian ini digunakan untuk mengetahui beberapa determinan (paritas, anemia dan kekurangan energi kronis pada kehamilan) kejadian BBLR. Kasus adalah bayi badan lahir rendah $<2500$ gr dilahirkan preterm atau aterm di wilayah Kecamatan Metro Barat saat penelitian tahun 2016, sedangkan kontrol adalah bayi badan lahir normal $\geq 2500$ gr yang memenuhi syarat penelitian dan dibatasi dengan kriteria inklusi dan ekskluasi.

Adapun jumlah sampel minimal yang diperlukan oleh peneliti 18 sampel kasus BBLR dengan sampel kontrol berjumlah 18 kasus yang tidak mengalami BBLR.

Pengambilan sampel dalam penelitian ini dilakukan secara berurutan saat penelitian, dan berhenti saat sampel telah terpenuhi. Jumlah sampel dihitung dengan nilai $\mathrm{OR}=10$ nilai $\mathrm{p} 1=0,82$ dan $\mathrm{p} 2=0,31$, maka didapatkan nilai $\mathrm{P}=0,56$ dihitung berdasarkan rumus besar sampel diatas dengan derajat kepercayaan $95 \%$ dan kekuatan uji 90\% dengan perbandingan 1:1 $(\mathrm{k}=1)$. Adapun jumlah sampel minimal yang diperlukan oleh peneliti 18 sampel kasus BBLR dengan sampel kontrol berjumlah 18 kasus yang tidak mengalami BBLR. Teknik sampel yang digunakan adalah consecutive sampling, yaitu teknik pengambilan sampel secara berurutan saat penelitian, dan berhenti saat sampel telah terpenuhi. Semua subjek yang memenuhi kriteria pemilihan disertakan sebagai sampel (Sastroasmoro \& Ismail, 2016).

Pengumpulan data penelitian bersumber dari catatan atau status rekam medik pasien yang melahirkan di Puskesmas Puskesmas Kota Metro tahun 2016. Instrumen yang digunakan adalah kuesioner bentuk check list untuk memperoleh data variabel penelitian dengan kriteria ukur: (1) kejadian BBLR dengan kriteria ya atau tidak; (2) anemia ibu hamil kriteria $\mathrm{Hb}<11$ gr\% dengan hasil ukur ya atau tidak; (3) kekurangan energi protein pada ibu hamil kriteria $<13,5 \mathrm{~cm}$ dengan hasil ukur ya atau tidak dan (4) paritas dengan hasil ukur berisiko ( $<1$ atau $>3$ anak) dan tidak berisiko (1-3 anak).

Data yang telah dikumpulkan dilakukan pengolahan data dan analisis data. Analisis data menggunakan analisis univariat (distribusi frekuensi dengan tabel) dan analisis bivariat untuk menguji determinan kejadian BBLR menggunakan uji chi-square. Besar asosiasi memenuhi syarat kemaknaan, jika prevalensi odd rasio $(\mathrm{POR})>1$ dan nilai $\mathrm{p}<0,05$ (Sastroasmoro \& Ismail, 2016). 


\section{Hasil}

\section{Gambaran variabel penelitian}

Variabel yang dianalisis secara univariat ditunjukkan pada tabel 1. Tabel 1 menunjukkan bahwa ibu bersalin dengan paritas berisiko ( 1 atau $>3$ anak) terdapat setengahnya (50\%), ibu yang memiliki riwayat anemia ada 36,1\%. Sedangkan, ibu hamil mengalami KEK selama kehamilan sejumlah 30,6\%

Tabel 1.

Distribusi riwayat raritas, anemia dan KEK pada ibu hamil

\begin{tabular}{llcc}
\hline \multicolumn{1}{c}{ Variabel } & \multicolumn{1}{c}{ Kategorik } & n=36 & Jumlah (\%) \\
\hline Paritas & Berisiko (1 atau $>3$ & 18 & 50 \\
& Tidak berisiko $(1-3$ anak) & 18 & 50 \\
Anemia & Ya $($ Hb $<11$ gr\%) & 13 & 36,1 \\
& Tidak $(\geq 11$ gr\%) & 23 & 63,9 \\
KEK (LILA $<35,5 \mathrm{~cm})$ & Ya & 11 & 30,6 \\
& Tidak & 25 & 69,4 \\
\hline
\end{tabular}

\section{Analisis Bivariat}

Analisis bivariat dilakukan untuk melihat hubungan antara senam hamil dengan lama persalinan menggunakan uji chi square dengan hasil pada tabel 2. Tabel 2 menunjukkan hasil uji statistik: (1) menunjukkan tidak ada hubungan antara anemia dengan kejadian BBLR karena nilai p 0,48 $(>0,05),(2)$ ada hubungan antara KEK dengan kejadian BBLR (nilai p 0,03), dan (3) ada hubungan antara paritas berisiko dengan kejadian BBLR karena nilai p 0,02 (> 0,05). Ibu hamil dengan KEK berisiko sebesar 8,0 kali melahirkan bayi dengan BBLR dibandingkan ibu yang tidak KEK dan ibu hamil dengan paritas 1 atau $>3$ anak memiliki resiko lebih besar 6,75 kali melahirkan Bayi dengan BBLR dibandingkan dengan ibu hamil yang memiliki paritas tidak berisiko.

Tabel 2.

Hasil analisis hubungan faktor anemia, KEK dan paritas dengan kejadian BBLR

\begin{tabular}{|c|c|c|c|c|c|c|c|c|}
\hline \multirow{2}{*}{ Variabel } & \multicolumn{2}{|c|}{ Kasus } & \multicolumn{2}{|c|}{ Kontrol } & \multirow{2}{*}{$\begin{array}{l}\mathbf{n} \\
\mathbf{n}\end{array}$} & \multirow{2}{*}{$\%$} & \multirow{2}{*}{$P$ value } & \multirow{2}{*}{$\begin{array}{c}\text { POR } \\
\text { (CI 95\%) }\end{array}$} \\
\hline & n & $\%$ & $\mathbf{n}$ & $\%$ & & & & \\
\hline \multicolumn{9}{|l|}{ Anemia } \\
\hline Anemia & 8 & 44,4 & 5 & 27,8 & 13 & 36,1 & \multirow[t]{2}{*}{0.48} & 2,4 \\
\hline Tidak Anemia & 10 & 55,6 & 13 & 72,2 & 23 & 63,9 & & $(0,6-0,9)$ \\
\hline \multicolumn{9}{|l|}{ KEK } \\
\hline Ya & 9 & 50 & 2 & 11 & 11 & 30,6 & \multirow[t]{2}{*}{0.03} & 8,0 \\
\hline Tidak & 9 & 50 & 16 & 89 & 25 & 69,4 & & $(1,4-22,0)$ \\
\hline \multicolumn{9}{|l|}{ Paritas } \\
\hline Berisiko & 13 & 72,2 & 13 & 72,2 & 26 & 72,2 & \multirow[t]{2}{*}{0.02} & $\begin{array}{c}6,75 \\
(1500)\end{array}$ \\
\hline Tidak berisiko & 5 & 27,8 & 5 & 27,8 & 10 & 27,8 & & $(1,15-29,0)$ \\
\hline
\end{tabular}

\section{Pembahasan}

\section{Kekurangan energi kronis dan kejadian BBLR}

Penelitian ini bertujuan menganalisis hubungan K EK dengan kejadian BBLR. Hasil analisis memperoleh ada hubungan antara KEK pada ibu hamil dengan kejadian BBLR dan dari 11 ibu hamil dengan KEK yang melahirkan bayi BBLR sebanyak 81,8 \%. Ibu hamil dengan KEK berisiko sebesar 8,0 kali melahirkan bayi dengan BBLR dibandingkan ibu yang tidak KEK 
Hasil penelitian ini sejalan dengan penelitian yang dilakukan oleh (Andayani \& Pradini, 2015) di Puskesmas II Sukawati Gianyar Bali menunjukkan hasil ada hubungan bermakna antara KEK ibu hamil dengan kejadian BBLR. Kejadian KEK dapat disebabkan oleh asupan nutrisi. Keadaan ini dapat menjadi penyebab kejadian BBLR adalah asupan nutrisi janin yang dibutuhkan kurang mencukupi (England, 2015). Ibu yang sedang hamil bersangkutan pula dengan proses pertumbuhan foetus yang ada dalam kandungan. Kondisi gizi dan konsumsi ibu yang sedang hamil akan berpengaruh pada kondisi foetus dan nonatus setelah lahir, yang berakibat BBLR (Sediaoetama, 1999). Implikasi ukuran LILA terhadap berat badan lahir bayi adalah bahwa LILA menggambarkan keadaan konsumsi makan terutama konsumsi energi, dan protein dalam jangka panjang. Kekurangan energi kronis menyebabkan tidak adanya cadangan zat gizi yang adekuat untuk menyediakan kebutuhan fisiologi selama kehamilan, yakni perubahan hormon dan meningkatnya volume darah untuk pertumbuhan janin, sehingga suplai zat gizi janin berkurang, yang mengakibatkan terhambatnya pertumbuhan dan perkembangan janin dan lahir dengan berat badan yang rendah (Departemen Kesehatan RI, 1995).

Penelitian ini memperlihatkan hasil analisis dari ibu hamil yang mengalami KEK dan melahirkan bayi BBLR sebanyak 81,8 \% dan Ibu hamil dengan KEK berisiko sebesar 8,0 kali melahirkan bayi dengan BBLR dibandingkan ibu yang tidak KEK. Kekurangan energi kronik merupakan salah satu keadaan malnutrisi patologis akibat kekurangan atau kelebihan secara relative atau absolut satu atau lebih zat gizi (Supariasa, 2012). Penyebab KEK dalam kehamilan diantaranya disebabkan oleh faktor sosial ekonomi, seperti pendapatan keluarga, pendidikan ibu, status perkawinan dan faktor biologis yaitu usia ibu hamil yang terlalu muda (kurang dari 20 tahun), jarak kehamilan kurang dari 2 tahun (Soetjiningsih, 2012). Paritas dan pola konsumsi yang dapat dipengaruhi oleh pengetahuan ibu, faktor perilaku dari kebiasaan yang sering dilakukan ibu diantaranya yaitu kebiasaan merokok dan mengkonsumsi kafein. Tingkat pengetahuan ibu hamil turut menentukan mudah tidaknya memahami pengetahuan gizi yang mereka peroleh untuk pertumbuhan dan perkembangan janin dalam rahim.

Deteksi dini berupa pemeriksaan dapat dilakukan petugas kesehatan dengan melakukan pengukuran lingkar lengan atas untuk mengetahui risiko terjadinya kekurangan energi kronis pada ibu hamil yaitu dengan LILA kurang dari $23,5 \mathrm{~cm}$, selain itu penyuluhan berupa nasehat makanan bergizi, persiapan persalinan oleh tenaga kesehatan, memeriksa kehamilan secara teratur dan tanda-tanda bahayanya serta pemanfaatan tanaman pekarangan, pengobatan penyakit yang melatar belakangi seperti TBC, malaria, anemia serta pemberiaan makanan tambahan (PMT) dapat dilakukan oleh petugas kesehatan

\section{Paritas dan kejadian BBLR}

Penelitian bertujuan mengetahui hubungan antara paritas dengan kejadian BBLR. Hasil penelitian menunjukkan ada hubungan antara paritas berisiko dengan kejadian BBLR dan dari ibu hamil dengan paritas berisiko ( 1 atau > 3 anak) yang melahirkan bayi BBLR sebanyak 72,2\%. Ibu hamil dengan paritas 1 atau > 3 anak memiliki resiko lebih besar 6,75 kali melahirkan Bayi dengan BBLR dibandingkan dengan ibu hamil yang memiliki paritas tidak berisiko. Hasil penelitian ini sejalan dengan penelitian yang dilakukan oleh (Hasanah, 2014) di RS Kariadi Semarang dan penelitian yang dilakukan oleh (Amalia, 2011) di RS swasta yang berada di wilayah Gorontalo yang menunjukkan hasil uji statistik ada hubungan antara paritas dengan lama persalinan ibu. Paritas 1 dan lebih dari 3 mempunyai resiko lebih besar melahirkan bayi BBLR dibandingkn paritas kurang dari 3 (Barends, dkk, 2005). Jumlah anak lebih dari 3 dapat menimbulkan gangguan pertumbuhan janin, sehingga melahirkan bayi dengan berat lahir rendah dan perdarahan saat persalinan karena keadaan rahim biasanya sudah lemah (Manuaba, 2012). 
Paritas ibu berisiko terjadinya BBLR tinggi pada paritas 1, kemudian menurun pada paritas 2 dan 3 dan meningkat kembali pada paritas 4 dan seterusnya (Manuaba, 2012), sedangkan (Joeharno, 2008) menyatakan bahwa BBLR dapat terjadi dengan ibu paritas tinggi. Pada ibu dengan kehamilan lebih dari 4 tubuhnya lebih lemah karena sering melahirkan bayi, menyusui dan merawat anaknya. Analisis penelitian ini menunjukkan Ibu hamil dengan paritas 1 atau > 3 anak memiliki resiko lebih besar 6,75 kali melahirkan Bayi dengan BBLR dibandingkan dengan ibu hamil yang memiliki paritas tidak berisiko. Ibu hamil dengan paritas berisiko ( 1 atau > 3 anak) yang melahirkan bayi BBLR sebanyak 72,2\%.

Upaya penurunan kasus BBLR urgen dilakukan karena terkait juga dengan kematian neonatal atau bayi. Hendaknya ibu hamil dengan paritas tinggi melakukan rutin kunjungan kehamilan untuk melakukan deteksi dini kemungkinan komplikasi kehamilan, sehingga penanganan dini dapat dilakukan dan melahirkan bayi BBLR dapat dicegah.

\section{Simpulan dan saran}

Hasil penelitian menyimpulkan Ibu hamil dengan KEK berhubungan bermakna dengan kejadian BBLR dan berisiko sebesar 8,0 kali melahirkan bayi dengan BBLR dibandingkan ibu yang tidak KEK. Ibu hamil dengan paritas berisiko ( 1 atau > 3 anak) berhubungan bermakna dengan kejadian BBLR dan memiliki resiko lebih besar 6,75 kali melahirkan Bayi dengan BBLR dibandingkan dengan ibu hamil yang memiliki paritas tidak berisiko. Hendaknya ibu hamil dengan paritas tinggi melakukan rutin kunjungan kehamilan untuk melakukan deteksi dini kemungkinan komplikasi kehamilan termasuk KEK, sehingga penanganan dini dapat dilakukan dan melahirkan bayi BBLR dapat dicegah.

\section{Referensi}

Amalia , L. (2011). Faktor-faktor resiko kejadian bayi berat lahir rendah (BBLR) di RSU dr. MM Dunda Limboto Kabupaten Gorontalo. Jurnal Gorontalo Universitas Negeri Gorontalo.

Andayani, N. W., \& Pradini, N. (2015). KEK pada masa kehamilan di Puskesmas II Sukawati Gianyar. Bali.

Arisman. (2010). Gizi dalam daur kehidupan : Buku ajar ilmu gizi. Jakarta: EGC.

Barends, dkk. (2005). Faktor-Faktor yang mempengaruhi perdarahan post partum. Jakarta : EGC.

Departemen Kesehatan RI. (1995). Pedoman penggunaan alat ukur LILA pasa WUS. Dinas Kesehatan Kota Metro , Dirjend gizi masyarakat. Jakarta: Profil Kesehatan Kota Metro tahun 2005.

Dinas Kesehatan Kota Metro . (2016). Profil kesehatan Kota Metro tahun 2015. Kota Metro: Dinas Kesehatan Kota Metro.

Dinas Kesehatan Provinsi Lampung. (2016). Profil kesehatan Provinsi Lampung tahun 2015. Lampung: Dinas Keesehatan Provinsi Lampung.

England. (2015). The healthy low birth weight baby. Churchill Livingstone Elsevier : Myles texbook for midwifes.

Fraser, Diane, M., Cooper, M. A. (2009). Buku ajar Bidan Myles, . Jakarta: EGC.

Hasanah. (2014). Faktor-faktor yang berhubungan dengan kejadian Bayi Berat lahir Rendah (BBLR) di ruang BRT RSU dr Kariadi Semarang Tahun 2010. Jurnal dinamika kebidanan, 4(2).

Joeharno. (2008). Faktor-faktor yang berhubungan dengan kejadian perdarahan post partum di RS Madani Medan. KTI, Klaten .

Manuaba, I. (2012). Ilmu kebidanan penyakit kandungan keluarga berencana untuk pendidikan bidan. Jakarta: EGC. Mochtar, R. (2005). Sinopsis Obstetri jilid I. Jakarta: EGC. 
Mustika. (2005). Kurang energi kronis dan anemia ibu hamil sebagai faktor risiko dengan kejadian BBLR. Retrieved Februari 24, 2016, from http://mayang10.files.wordpress.com/2010/03/jurnal-2.pdf

Mutalazimah. (2005). Hubungan kekurangan energy kronis dengan kejadiaan BBLR. Retrieved February 24, 2016, from http://eprints.ums.ac.id

Saifuddin, A. B. (2009). Buku acuan nasional pelayanan kesehatan maternal dan neonatal. Jakarta: Yayasan Bina Pustaka Sarwono Prawirohardjo.

Sastroasmoro, S. \& Ismael, S. (2016). Dasar-dasar metodologi penelitian klinis. 5 (ed). Jakarta: Seto Agung

Sediaoetama. (1999). Ilmu Gizi. Jakarta: Universitas Indonesia.

Setiawa, R., Melani. R., \& Dirgahayu, I. (2009). Hubungan anemia pada ibu hamil dengan kejadian BBLR di Ruang Perinatologi RSU dr Slamet Garut. Jawa Barat.

Soetjiningsih. (2012). Tumbuh Kembang Anak. Jakarta: EGC.

Supariasa. (2012). Pendidikan dan Konsultasi Gizi. Jakarta: EGC.

Varney, H. (2007). Buku Ajar Asuhan Kebidanan. Jakarta: EGC. 